\section{Factors associated with mortality} after decompressive craniectomy in large basal ganglia bleeds

\author{
Amit Kumar Thotakura*, Nageswara Rao Marabathina, Rama \\ Krishnareddy Mareddy and Sivaramanjaneyulu Yeddanapudi \\ Department of Neurosurgery, NRI Academy of Sciences, Chinakakani, Guntur, 522503, Andhra \\ Pradesh, India
}

\section{Abstract}

Aim: To assess the efficacy of decompressive craniectomy in patients with large basal ganglia (BG) bleed. To establish predictive criteria of mortality after surgery in patients with BG bleed.

Materials: This prospective study includes all patients of large spontaneous BG bleed operated by decompressive craniectomy without hematoma evacuation from October 2012 to September 2015. Data was collected on patient age, gender, distribution of bleed, affected hemisphere dominancy, preexisting medical conditions, admission Glasgow Coma Score (GCS), midline shift on CT or MRI Brain, hematoma volume and anisocoria, duration (hours) between the onset of stroke and operation, post-operative complications, and the duration of hospital stay. This data was correlated with one month mortality of the patients.

Results: Total number of patients were 27. Mean age was 51 years and mean GCS was 7.55 (range 5-11). The mean volume of the bleed was $68.51 \mathrm{ml}$. Mortality was noted in 17 out of 27 patients $(63 \%)$ in 30 days. Thirteen of the 16 patients with intraventricular extension of BG bleed had mortality. The factors that showed statistically significant correlation with one month mortality were age, GCS at admission, volume of the bleed and the intraventricular extension.

Conclusion: Large BG bleed was associated with high mortality and morbidity. Age of 50 years or more and GCS $\leq 8$ at presentation were poor prognostic factors for decompressive craniectomy in patients with BG bleed. Patients with large BG bleed of volume $>60 \mathrm{ml}$ and intraventricular extension had poor prognosis.

\section{More Information}

*Address for Correspondence: Dr. Amit Kumar Thotakura, Department of Neurosurgery, NRI Academy of Sciences, Chinakakani, Mangalagiri, Guntur 522503, Andhra Pradesh, India, Tel: 7799465555; Email: doctoramitkumar@gmail.com

Submitted: February 10, 2021

Approved: May 10, 2021

Published: May 11, 2021

How to cite this article: Thotakura AK, Marabathina NR, Mareddy RK, Yeddanapudi S Factors associated with mortality after decompressive craniectomy in large basal ganglia bleed. J Neurosci Neurol Disord. 2021; 5: 029-033.

DOI: 10.29328/journal.jnnd.1001048

Copyright: (c) 2021 Thotakura AK, et al. This is an open access article distributed under the Creative Commons Attribution License, which permits unrestricted use, distribution, and reproduction in any medium, provided the original work is properly cited.

Keywords: Large ICH; Outcome; Decompressive craniectomy; Surgery for $\mathrm{ICH}$; Capsuloganglionic bleed; Basal ganglia bleed

Abbreviations: GCS: Glasgow Coma Scale; GOS: Glasgow Outcome Scale; BG Bleed: Basal Ganglia Bleed; ICH: Intracerebral Hematoma; CT: Computed Tomography; MRI: Magnetic Resonance Imaging; IVH: Intraventricular Hematoma

Check for updates

OPEN ACCESS

\section{Introduction}

The role of surgery in haemorrhagic stroke is not defined properly. Various surgical procedures were described earlier for deep seated intracerebral hematoma (ICH) [1]. We want to present the results of a case series of patients with large basal ganglia hematoma, who were operated by only Decompressive Craniectomy without clot evacuation. This procedure was studied by some authors earlier [2-5].

The objective of our study was to assess the efficacy of decompressive craniectomy in patients with large Basal ganglia (BG) bleed. To establish predictive criteria of mortality after surgery in patients with BG bleed.

\section{Methods}

This prospective study includes all patients of large spontaneous BG bleed operated by decompressive craniectomy without hematoma evacuation from October 2012 to September 2015 at NRI Academy of Sciences.

Patients presenting with spontaneous BG bleed were admitted in neuro intensive care unit. Stroke was diagnosed by clinical history, physical examination and head CT. All the patients were examined neurologically, observed in the intensive care unit. They were intubated, and ventilated, when necessary. All these patients were given anti edema agents, such as Mannitol and Furosemide. They were monitored clinically without invasive ICP monitoring. Clinical neurological deterioration was defined by drop in GCS by 2 points with a minimum drop in motor score by 1 . If the patient began to deteriorate neurologically, emergency repeat head CT was performed. When clinical deterioration correlated with radiological findings of increase in mass effect, then emergency decompressive craniectomy was performed. 
All the patients with basalgangliableed extendingto internal capsular region and involving thalamic regions were included in the study. Patients with severe medical co-morbidity, age $>70$ years, bleed caused by trauma, primary intraventricular hemorrhage, posterior fossa bleeds, supratentorial lobar bleeds, disorders of blood coagulation were excluded from the study. Data was collected on patient age, gender, distribution of bleed, affected hemisphere dominancy, preexisting medical conditions or risk factors, admission Glasgow Coma Score (GCS), papillary asymmetry, midline shift on CT or MRI Brain, hematoma volume, duration between the onset of stroke and surgery, post-operative complications and duration of hospital stay. The three dimensions of the hematoma were measured in centimeters (length, breadth, height) and the volume in $\mathrm{cm}^{3}$ was calculated by the formula lxbxh divided by 2 .

\section{Surgical technique}

The patient is positioned supine with the head turned contralaterally about 45 degrees. A skin marking for standard decompressive craniectomy was given. Scalp along with temporalis muscle was elevated. A free bone craniectomy flap measuring $13 \times 10 \mathrm{~cm}$ was done and harvested in the anterior abdominal wall. Dura opened in a curvilinear fashion to the bony margins. Duroplasty was done with pericranium. Scalp closed in layers.

In the follow up, the patients were assessed with Glasgow outcome scale (GOS) at 1 month and 3 months time. The Institutional Ethical Committee approval was taken to conduct the study. Descriptive statistics of patient variables were calculated. The correlation between survival group and mortality group was tested with Fischer exact test in case of categorical variables and with student ' $t$ ' test in case of continuous variables.

\section{Results}

Total number of patients were 27 , out of which males were $22(81.5 \%)$. Age range of the patients was 38 to 70 years with mean of 51 years. History of alcoholism was present in 11 patients (40.74\%) where as that of smoking was present in 9 patients (33.3\%). Risk factor like hypertension was present in 19 patients $(70.37 \%)$ where as diabetes mellitus was noted in 7 patients $(25.9 \%)$. The details of all the 27 patients were given in table 1.

The range of pre-operative GCS is 5 - 11 with mean of 7.55. Twenty of the 27 patients (74\%) are with the pre-operative GCS of $\leq 8$. The pupillary asymmetry was present in 7 patients. The side of lesion was on right side in 16 patients and on the left side in 11 patients. The mean midline shift of all the patients was $9.45 \mathrm{~mm}$. The range of midline shift was from $5-16 \mathrm{~mm}$.

Mortality was noted in 17 out of 27 patients (63\%) in 30 days. The survival group consists of 10 patients. The range of GCS in the survival group was $7-10 \mathrm{ml}$ whereas that in the mortality group was $6-11 \mathrm{ml}$. The mean GCS in the survival group was 8.3 compared to the mean GCS of the mortality group of 7.58. The factors compared between survival and mortality group were shown in table 2 .

The mean interval between ictus and the surgery was 42.5 hours. The mean interval in the mortality group was 47.18 hours and that of survival group was 34.6 hours ( $p=0.5218$ ). Though the time of intervention was early in the survival group there was no statistical difference between the two groups probably because of small numbers.

The mean volume of the bleed in all the patients was $68.51 \mathrm{ml}$. The mean volume of the bleed in the survival group was $53.5 \mathrm{ml}$ where as that of the mortality group was 77.35 $\mathrm{ml}(p=0.0081)$. Patients with large volume $(>60 \mathrm{ml})$ of bleed were 16 in number (59.3\%). Only three of the 16 patients survived. The largest volume of the bleed survived was $76 \mathrm{ml}$ in a 40 year old patient. The range of the volume of the bleed in survival group was $32-76 \mathrm{ml}$ whereas that in mortality group was $31-113 \mathrm{ml}$.

The average follow up of the patients was 4.2 months with range of 3 to 8 months. The GOS at 3 months was four in 5 patients and three in 4 patients and one in 1 patient. One patient had died at $2 \frac{1}{2}$ months time with cardiac failure.

\section{Discussion}

Intracerebral hemorrhage accounts for $10 \%$ to $15 \%$ of all

Table 1: Various factors and their comparison between survival group and mortality group.

\begin{tabular}{|c|c|c|c|}
\hline $\mathrm{N}=27$ & Survival group & Mortality group & $\boldsymbol{p}$ value \\
\hline Mean Age & 10 & 17 & - \\
\hline Mean GCS & 86.5 & 53.7 & $\begin{array}{c}0.0294 \\
\text { (student t test) }\end{array}$ \\
\hline $\begin{array}{c}\text { Pupillary asymmetry } \\
\text { present (7) }\end{array}$ & 3 & 7.12 & $\begin{array}{c}0.0306 \\
\text { (student t test) }\end{array}$ \\
\hline $\begin{array}{c}\text { Left side of the lesion (11) } \\
\text { Mean midline shift in mm }\end{array}$ & 8.74 & 7 & $\begin{array}{c}1.0000 \text { (Fischer } \\
\text { exact test) }\end{array}$ \\
\hline $\begin{array}{c}\text { Mean volume of the bleed } \\
\text { in ml }\end{array}$ & 53.5 & 77.35 & $\begin{array}{c}1.0000 \text { (Fischer } \\
\text { exact test) }\end{array}$ \\
\hline $\begin{array}{c}\text { Intraventricular extension of } \\
\text { the bleed present (16) }\end{array}$ & 3 & 13 & $\begin{array}{c}0.3279 \\
\text { (student t test) }\end{array}$ \\
\hline (student t test) \\
\hline
\end{tabular}

Table 2: Various studies which showed the significance of GCS and volume of ICH as outcome predictors.

\begin{tabular}{|c|c|}
$\begin{array}{c}\text { GCS as predictor of } \\
\text { poor outcome }\end{array}$ & Studies \\
\hline$\leq 8$ & Li [9], Bhatia [10], Broderick [12], Tuhrim [13], Yousuf [14] \\
\hline$<8$ & Suthar [15], Nilsson [16], Present study \\
\hline $\begin{array}{c}\text { Volume as predictor of } \\
\text { poor outcome }\end{array}$ & Studies \\
\hline $25 \mathrm{ml}$ & Tshikwela [17] \\
\hline $30 \mathrm{ml}$ & $\begin{array}{c}\text { Hemphill III [18], Sia [19], Cho [20], Nag [21], Suthar } \\
\text { [15], Celikbilek [22], Safatli (32 ml) [23] }\end{array}$ \\
\hline $40 \mathrm{ml}$ & $\begin{array}{r}\text { Franke [24]. Bhatia [10] (42 ml) } \\
\text { Helweg-Larsen [6], Narayan [25], Li [9] }\end{array}$ \\
\hline $50 \mathrm{ml}$ & $\begin{array}{c}\text { Broderick [12], Nilsson [16], Yousuf [14], Zia [26], Lin \& } \\
\text { Howng [27], Present study }\end{array}$ \\
\hline $60 \mathrm{ml}$ &
\end{tabular}


cases of stroke and is associated with the highest mortality, with only $38 \%$ of affected patients surviving the first year [6]. Helweg-Larsen, et al. showed that the survival within 1 month in the hospital was $50 \%$ to $60 \%$ for patients with hematoma of the basal ganglia [6].

Brief review of literature was done regarding the various factors (Age, GCS, Volume of ICH, intraventricular haemorrhage) that affect the outcome in patients with $B G$ bleed.

Age: Kanno, et al. noted a better long term outcome in younger patients ( $<59$ years) [7]. Similarly Kilincer, et al, concluded that age $\geq 60$ years is a predictor of poor outcome [8]. In our study, 12 of the 15 patients (80\%) with age of 50 years or more had mortality. Age more than 50 years is a poor prognostic factor in patients with basal ganglia bleed.

GCS: GCS was an important predictor of outcome in patients with ICH. This was confirmed by many authors (Table 2). $\mathrm{Li}$, et al. in a retrospective study of surgical treatment for large spontaneous basal ganglia hemorrahge, concluded GCS $\leq 8$ as the risk factor for unfavourable outcome [9]. Bhatia, et al. in his prospective study of in-hospital mortality and discharge outcome in spontaneous ICH concluded thatlow GCS $(\leq 8)$ is an independent predictor of mortality [10]. Takeuchi, et al. in a retrospective study of large hemispheric hypertensive $\mathrm{ICH}$, concluded that low preoperative GCS results in poor outcome [11]. In our study, there is significant statistical difference between mean GCS of survival group (8.3) and that of mortality group (7.58). GCS less than 8 is a poor prognostic factor in patients with basal ganglia bleed.

Volume of ICH: Volume of intracerebral hemorrhage was the strongest predictor of 30-day mortality for all locations of intracerebral hemorrhage [12]. They predicted 30 day mortality in a patient with GCS 8 or less with parenchymal

Table 3: The 30 day mortality rates of patients with small $(<30 \mathrm{ml})$, medium $(30-60 \mathrm{ml})$ and large (>60 ml) basal ganglia bleeds in various studies.

\begin{tabular}{|c|c|c|c|}
\hline $\begin{array}{c}\text { Data regarding deep/ } \\
\text { basal ganglia bleeds }\end{array}$ & $\begin{array}{c}\mathbf{3 0} \text { day mortality } \\
\text { for volume }< \\
\mathbf{3 0 ~} \mathbf{~ m l}\end{array}$ & $\begin{array}{c}\mathbf{3 0} \text { day mortality } \\
\text { for volume } \\
\mathbf{3 0 - 6 0} \mathbf{~ m l}\end{array}$ & $\begin{array}{c}\mathbf{3 0} \text { day mortality } \\
\text { for volume } \\
\mathbf{6 0 ~} \mathbf{~ m l}\end{array}$ \\
\hline Broderick et al. [12] USA & $23 \%$ & $64 \%$ & $93 \%$ \\
\hline Nilsson et al. [16] Sweden & $30 \%$ & $41 \%$ & $77 \%$ \\
\hline Yousuf et al. [14] Malaysia & $12.9 \%$ & $41.4 \%$ & $63.0 \%$ \\
\hline Present study & - & $36.4 \%$ & $81 \%$ \\
\hline
\end{tabular}

hemorrhage volume of $60 \mathrm{ml}$ or more on their initial computed tomogram to be $91 \%$. Helweg-Larsen, et al. showed that the mortality of patients with ICH of $50 \mathrm{ml}$ or more will be $90 \%$ [6]. Similarly, various authors studied and found hematoma volume of ICH as poor predictor of outcome (Table 3). In our study, 13 of the 16 patients (81.25\%) with volume of bleed more than $60 \mathrm{ml}$ had mortality. Volume more than $60 \mathrm{ml}$ is a poor prognostic factor in patients with basal ganglia bleed. This is comparable to mortality rate noted in similar patients of other studies. However, nearly two-thirds of patients with ICH volume 30 - $60 \mathrm{ml}$ could survive after surgery (Table 4).

IVH: Hallevi, et al. found that patients with IVH were twice as likely to have a poor outcome when compared to patients without IVH [28]. Bhatia, et al. [10] and Nag, et al. [21]. Also concluded that presence of IVH is an independent predictor of mortality. Poor outcome was noted in patients with intra ventricular extension by Narayan, et al. [25]. In the present study, the mortality rate in patients with intraventricular extension is $81.25 \%$ (13 of the 16 patients). Intraventricular extension is a poor prognostic factor in patients with basal ganglia bleed.

Decompressive Craniectomy without clot evacuation was shown to be effective in cases of ICH earlier. Earlier four studies including the present study was tabulated (Table 5). The present study along with Ramnarayan, et al. study were larger studies including patients with only basal ganglia bleed. The mortality was high in the present study due to large mean ICH volume $(68.5 \mathrm{ml})$ and more percentage of patients with IVH (nearly 60\%).

\section{Limitations}

This hospital-based single center study did not provide true prevalence of ICH in the community. Sample size was small and the follow-up period of three months allowed only short term outcome assessment. This study included only operative patients but not conservatively treated patients.

\section{Future scope}

Multicenter study can be done on large number of patients to define the guidelines and indications of surgery in patients of ICH. The Decompressive craniectomy can be compared to newer surgical procedures like endoscopic evacuation of hematoma particularly in large deep seated ICH.

Table 4: Studies with decompressive craniectomy without clot evacuation done for ICH.

\begin{tabular}{|c|c|c|c|c|c|c|c|}
\hline Author & Study design & $\mathbf{N}$ & Age & $\begin{array}{l}\text { Level of pre-operative } \\
\text { consciousness }\end{array}$ & Hematoma location & $\begin{array}{l}\text { No. of patients } \\
\text { with IVH }\end{array}$ & Volume \\
\hline Ramnarayan et al. [2] & Case series & 23 & $31-68$ & $\mathrm{GCS} \leq 8(7)$ & Basal ganglia (23) & 6 & $\begin{array}{c}>60 \mathrm{ml} \text { in } 7 \\
\text { patients }\end{array}$ \\
\hline Fung et al. [3] & Case control & 12 & 48 (median) & 8 (median) & $\begin{array}{l}\text { Basal ganglia (5), } \\
\quad \text { lobar }(7)\end{array}$ & NA & $61.25 \mathrm{ml}$ (median) \\
\hline Heuts et al. [4] & Prospective study & 5 & 43 (mean) & 7 (median) & $\begin{array}{c}\text { Basal ganglia (3), } \\
\text { lobar (2) }\end{array}$ & 2 & $53 \mathrm{ml}$ (median) \\
\hline Esquenazi et al. [5] & $\begin{array}{c}\text { uncontrolled retrospective } \\
\text { series }\end{array}$ & 10 & 48 (mean) & 11 (mean) & $\begin{array}{l}\text { Basal ganglia, deep } \\
\text { lobar }\end{array}$ & NA & $75 \mathrm{ml}$ (mean) \\
\hline Present study & Prospective study & 27 & 51 (mean) & 7.55 (mean) & Basal ganglia (27) & 16 & $68.51 \mathrm{ml}$ (mean) \\
\hline
\end{tabular}




\begin{tabular}{|c|c|c|c|c|c|c|c|c|c|c|c|c|}
\hline $\begin{array}{l}\text { serial } \\
\text { no. }\end{array}$ & $\begin{array}{l}\text { age in } \\
\text { years }\end{array}$ & gender & $\begin{array}{l}\text { pupillary } \\
\text { asymmetry }\end{array}$ & $\begin{array}{l}\text { side of the } \\
\text { lesion }\end{array}$ & $\begin{array}{c}\text { midline } \\
\text { shift in } \mathrm{mm}\end{array}$ & volume in $\mathrm{ml}$ & IVH & Hypertension & $\begin{array}{l}\text { Diabetes } \\
\text { mellitus }\end{array}$ & $\begin{array}{l}\text { pre op } \\
\text { gcs }\end{array}$ & $\begin{array}{l}\text { interval between } \\
\text { ictus and surgery }\end{array}$ & $\begin{array}{c}\text { GOS at } \\
\text { discharge }\end{array}$ \\
\hline 1 & 44 & $M$ & present & right & 8 & 50 & absent & yes & no & 9 & 47 & 3 \\
\hline 2 & 38 & M & absent & right & 16 & 113 & absent & yes & no & 5 & 7 & 1 \\
\hline 3 & 65 & M & absent & left & 8 & 32 & absent & yes & no & 7 & 12 & 3 \\
\hline 4 & 57 & M & absent & right & 10 & 86 & absent & yes & no & 8 & 246 & 1 \\
\hline 7 & 70 & M & absent & right & 8 & 75 & present & no & yes & 6 & 7 & 1 \\
\hline 8 & 47 & $\mathrm{~F}$ & absent & left & 8 & 75 & absent & yes & no & 6 & 63 & 1 \\
\hline 9 & 39 & M & absent & right & 13 & 62 & present & yes & no & 7 & 64 & 3 \\
\hline 10 & 61 & M & absent & left & 14 & 86 & present & yes & no & 8 & 57 & 1 \\
\hline 11 & 58 & $\mathrm{~m}$ & present & right & 9 & 104 & absent & yes & no & 6 & 15 & 1 \\
\hline 12 & 66 & M & present & right & 13 & 98 & absent & no & no & 6 & 35 & 1 \\
\hline 17 & 40 & $M$ & absent & right & 13 & 60 & present & yes & no & 7 & 57 & 3 \\
\hline 18 & 50 & $M$ & absent & right & 13 & 70 & present & yes & yes & 6 & 15 & 1 \\
\hline 19 & 55 & $M$ & present & left & 8 & 60 & present & yes & no & 9 & 35 & 1 \\
\hline 20 & 52 & $\mathrm{~F}$ & absent & right & 5 & 31 & present & yes & yes & 7 & 20 & 1 \\
\hline 21 & 44 & $M$ & present & right & 8 & 56 & absent & yes & no & 9 & 81 & 3 \\
\hline 22 & 52 & $M$ & absent & left & 10 & 110 & present & yes & no & 6 & 10 & 1 \\
\hline 23 & 40 & M & absent & left & 9.4 & 76 & absent & no & no & 9 & 15 & 3 \\
\hline 24 & 56 & M & absent & right & 10 & 72 & present & no & no & 7 & 64 & 1 \\
\hline 25 & 51 & $\mathrm{~F}$ & absent & right & 7 & 92 & absent & no & yes & 7 & 12 & 1 \\
\hline 26 & 52 & $\mathrm{~F}$ & absent & left & 6 & 39 & absent & no & yes & 8 & 24 & 3 \\
\hline 27 & 49 & $M$ & absent & left & 11 & 76 & present & yes & no & 8 & 26 & 1 \\
\hline
\end{tabular}

\section{Conclusion}

Large intracerebral hemorrhage is associated with high mortality and morbidity. Age of 50 years or more and GCS $\leq 8$ at presentation are poor prognostic factors for decompressive craniectomy in patients with BG bleed. Patients with large BG bleed (ICH volume $>60 \mathrm{ml}$ ) and intraventricular extension will have poor outcome.

\section{References}

1. Takeuchi S, Wada K, Nagatani K, Otani N, Mori K. Decompressive hemicraniectomy for spontaneous intracerebral hemorrhage. Neurosurg Focus. 2013; 34: E5.

PubMed: https://pubmed.ncbi.nlm.nih.gov/23634924/

2. Ramnarayan R, Anto D, Anilkumar TV, Nayar R. Decompressive hemicraniectomy in large putaminal hematomas: an Indian experience. J Stroke Cerebrovasc Dis. 2009; 18: 1-10.

PubMed: https://pubmed.ncbi.nlm.nih.gov/19110137/

3. Fung $C$, Murek M, Z'Graggen WJ, Krähenbühl AK, Gautschi OP, et al. Decompressive hemicraniectomy in patients with supratentorial intracerebral hemorrhage. Stroke. 2012; 43: 3207-3211. PubMed: https://pubmed.ncbi.nlm.nih.gov/23111437/

4. Heuts SG, Bruce SS, Zacharia BE, Hickman ZL, Kellner CP, et al Decompressive hemicraniectomy without clot evacuation in dominantsided intracerebral hemorrhage with ICP crisis. Neurosurg Focus. 2013; 34: E4.

PubMed: https://pubmed.ncbi.nlm.nih.gov/23634923/

5. Esquenazi Y, Savitz SI, El Khoury R, McIntosh MA, Grotta JC, et al. Decompressive hemicraniectomy with or without clot evacuation for large spontaneous supratentorial intracerebral hemorrhages. Clin
Neurol Neurosurg. 2015; 128: 117-122.

PubMed: https://pubmed.ncbi.nlm.nih.gov/25496934/

6. Helweg-Larsen S, Sommer W, Strange P, Lester J, Boysen G. Prognosis for patients treated conservatively for spontaneous intracerebral hematoma. Stroke. 1984; 15: 1045-1048.

PubMed: https://pubmed.ncbi.nlm.nih.gov/6506116/

7. Kanno T, Nagata J, Hoshino M, Nakagawa T, Asai T, et al. Evaluation of hypertensive intracerebral haematomas based on the study of long term outcome-part IV prognostic importance of the age of the patient and the laterality of the lesion in putaminal haemotoma. No shinkei geka. Neurological Surg. 1986; 14: 1539-1545.

PubMed: https://pubmed.ncbi.nlm.nih.gov/3822054/

8. Kilincer C, Asil T, Utku U, Hamamcioglu MK, Turgut N, et al. Factors affecting the outcome of Decompressive craniectomy for large hemispheric infarction: a prospective study. Acta Neurochir (Wien). 2005; 147: 587-594.

PubMed: https://pubmed.ncbi.nlm.nih.gov/15739038/

9. Li Q, Yang $\mathrm{CH}, \mathrm{Xu}$ JG, Li H, You C. Surgical treatment for large spontaneous basal ganglia haemorrhage:retrospective analysis of 253 cases. Br J Neurosurg. 2013; 27: 617-621.

PubMed: https://pubmed.ncbi.nlm.nih.gov/23406426/

10. Bhatia R, Singh H, Singh S, Padma MV, Prasad K, et al. A prospective study of in-hospital mortality and discharge outcome in spontaneous intracerebral hemorrhage. Neurol India. 2013; 61: 244-248. PubMed: https://pubmed.ncbi.nlm.nih.gov/23860142/

11. Takeuchi S, Takasato $\mathrm{Y}$, Masaoka $\mathrm{H}$, Hayakawa $\mathrm{T}$, Yatsushige $\mathrm{H}$, et al. Decompressive craniectomy with haematoma evacuation for large hemispheric hypertensive intra cerebral haemorrhage. Acta Neurochir Suppl. 2013; 118: 277-279.

PubMed: https://pubmed.ncbi.nlm.nih.gov/23564148/

12. Broderick JP, Brott TG, Duldner JE, Tomsick T, Huster G. Volume of 
intracerebral hemorrhage. A powerful and easy-to-use predictor of 30day mortality. Stroke. 1993; 24: 987-993.

PubMed: https://pubmed.ncbi.nlm.nih.gov/8322400/

13. Tuhrim S, Dambrosia JM, Price TR, Mohr JP, Wolf PA, et al. Prediction of intracerebral hemorrhage survival. Ann Neurol. 1988; 24: 258-263. PubMed: https://pubmed.ncbi.nlm.nih.gov/3178180/

14. Yousuf RM, Fauzi ARM, Jamalludin AR. Predictors of in-hospital mortality in primary intracerebral haemorrhage in East coast of Peninsular Malaysia. Neurology Asia. 2012; 17: 93-99.

15. Suthar NN, Patel KL, Saparia C, Parikh AP. Study of clinical and radiological profile and outcome in patients of intracranial hemorrhage. Ann Afr Med. 2016; 15: 69-77.

PubMed: https://pubmed.ncbi.nlm.nih.gov/27044730/

16. Nilsson OG, Lindgren $A$, Brandt $L$, Säveland $H$. Prediction of death in patients with primary intracerebral hemorrhage: A prospective study of a defined population. J Neurosurgery. 2002; 97: 531-536.

PubMed: https://pubmed.ncbi.nlm.nih.gov/12296635/

17. Tshikwela ML, Longo-Mbenza B. Spontaneous intracerebra hemorrhage: Clinical and computed tomography findings in predicting in-hospital mortality in Central Africans. J Neurosci Rural Pract. 2012; 3: $115-120$.

PubMed: https://pubmed.ncbi.nlm.nih.gov/22865958/

18. Hemphill JC, 3rd, Bonovich DC, Besmertis L, Manley GT, Johnston SC. The ICH score: A simple, reliable grading scale for intracerebral hemorrhage. Stroke. 2001; 32: 891-897.

PubMed: https://pubmed.ncbi.nlm.nih.gov/11283388/

19. Sia SF, Tan KS, Waran V. Primary intracerebral haemorrhage in Malaysia: in-hospital mortality and outcome in patients from a hospital based registry. Med J Malaysia. 2007; 62: 308-312.

PubMed: https://pubmed.ncbi.nlm.nih.gov/18551935/

20. Cho DY, Chen CC, Lee HC, Lee WY, Lin HL. Glasgow Coma Scale and hematoma volume as criteria for treatment of putaminal and thalamic intracerebral hemorrhage. Surg Neurol. 2008; 70: 628-633. PubMed: https://pubmed.ncbi.nlm.nih.gov/18207500/
21. Nag C, Das K, Ghosh M, Khandakar MR. Prediction of clinical outcome in acute haemorrhagic stroke from a single CT scan on admission. N Am J Med Sci. 2012; 4: 463-467.

PubMed: https://pubmed.ncbi.nlm.nih.gov/23112967/

22. Celikbilek A, Goksel BK, Zararsiz G, Benli S. Spontaneous intracerebral hemorrhage: A retrospective study of risk factors and outcome in a Turkish population. J Neurosci Rural Pract. 2013; 4: 271-277. PubMed: https://www.ncbi.nlm.nih.gov/pmc/articles/PMC3821411/

23. SafatliDA, Günther A, Schlattmann P, SchwarzF, KalffR, etal. Predictors of 30-day mortality in patients with spontaneous primary intracerebral hemorrhage. Surg Neurol Int. 2016; 1: 7(Suppl 18): S510-517. PubMed: https://pubmed.ncbi.nlm.nih.gov/27583176/

24. Franke CL, van Swieten JC, Algra A, van Gijn J. Prognostic factors in patients with intracerebral haematoma. J Neurol Neurosurg Psychiatry. 1992; 55: 653-657.

PubMed: https://www.ncbi.nlm.nih.gov/pmc/articles/PMC489199/

25. Narayan SK, Sivaprasad P, Sushma S, Sahoo RK, Dutta TK. Etiology and outcome determinants of intracerebral hemorrhage in a south Indian population, A hospital-based study. Ann Indian Acad Neurol. 2012; 15: 263-266.

PubMed: https://pubmed.ncbi.nlm.nih.gov/23349590/

26. Zia E, Engstrom G, Svensson PJ, Norrving B, Pessah-Rasmussen H. Three-Year Survival and Stroke Recurrence Rates in Patients With Primary Intracerebral Hemorrhage. Stroke. 2009; 40: 3567-3573. PubMed: https://pubmed.ncbi.nlm.nih.gov/19729603/

27. Lin CL, Howng SL. Surgical outcome of hypertensive putaminal hemorrhage in patients older than 65 years. Kaohsiung J Med Sci. 1998; 14: 280-285.

PubMed: https://pubmed.ncbi.nlm.nih.gov/9619013/

28. Hallevi $\mathrm{H}$, Albright KC, Aronowski J, Barreto AD, Martin-Schild S, et al. Intraventricular haemorrhage:Anatomic relationship and clinical implications Neurology. 2008; 70: 848-852.

PubMed: https://pubmed.ncbi.nIm.nih.gov/18332342/ 